\title{
Effect of Foliar Application of Nutrients on Biological Yield and Economics Urdbean (Vigna mungo (L.) Hepper)
}

\section{Dharmendra Meena*, Chandra Bhushan, Anil Shukla, Sumit Chaudhary and Shiv Singh Meena}

Department of Agronomy, Department of Soil science, College of Agriculture, G.B. Pant University of Agriculture and Technology, Pantnagar-263145, U.K., India

*Corresponding author

\section{A B S T R A C T}

\section{Keywords}

Borax, Foliar application, B: C ratio, Urea, Urdbean, Zinc-EDTA.

Article Info Accepted: 25 April 2017 Available Online: 10 May 2017
A field experiment was conducted during kharif 2014 at N. E. Borlaug Crop Research Centre of Govind Ballabh Pant University of Agriculture and Technology, Pantnagar to assess the effect of foliar application of nutrients on ecomomics of urdbean. The experiment was conducted in RBD (randomized block design) having twelve treatments with three replications. The data on economic studies revealed that the maximum biological yield, net returns and B: C ratio were made under T12 (2\% Urea $+2 \% \mathrm{SSP}+0.1 \%$ Zinc EDTA + $0.2 \% \mathrm{~B}$ (Borax), whereas, the minimum remained under the water spray.

\section{Introduction}

Pulses are commonly known as food legumes which are secondary to cereals in production and consumption in India. Pulses are an important source of dietary protein, energy, minerals and vitamins for the mankind. $d$. Pulses provide 25 per cent of protein requirements of predominantly vegetarian population. The World Health Organisation (WHO) recommends a per capita consumption of pulses at $80 \mathrm{~g}$ per day and the Indian Council of Medical Research has recommended a minimum consumption of 47 g. Pulses play an important role in Indian Agriculture as they restore soil fertility by fixing atmospheric nitrogen through their nodules. Urdbean is the fourth most important pulse crop after chickpea, pigeonpea and green gram in India. It contains $48.0 \%$ carbohydrates, $22.3 \%$ protein, $154 \mathrm{mg}$ calcium, $9.1 \mathrm{mg}$ iron, $1.4 \mathrm{~g}$ fat, $0.37 \mathrm{~g}$ riboflavin and $0.42 \mathrm{mg}$ thiamin in per $100 \mathrm{~g}$ of urdbean (Asaduzzaman et al., 2010). All India area, production and productivity of urdbean was $3.11 \mathrm{~m}$ ha, $1.90 \mathrm{~m}$ tones and 611 $\mathrm{kg} / \mathrm{ha}$, respectively, during 2012-13 (Anonymous, 2014). The yield potential of blackgram is very low because of the fact that, the crop is mainly grown in rainfed 
conditions with poor management practices and also due to various physiological, biochemical as well as inherent factors associated with crop (Shashikumar et al., 2012).

Physiological problem like flower drop and premature shedding of reproductive structure diminishes the number of potential sinks (or) accumulation of assimilates (Writer, 1986) which seems to be associated with nutrient deficiency and hormonal imbalance and ultimately with the reduced translocation of dry matter to reproductive parts.

The poor production potential of pulses is attributed to poor photosynthate of pods and seed setting, which may be improved through foliar application of macro and micronutrients and growth regulators.

Consequently applications of nutrients elements through foliar spray at appropriate stages of growth become important for their efficient utilization and better performance of the crop (Selim, 1992).

Foliar application of nutrients constitutes one of the important milestones in the progress of agricultural production. Fertilizer applied to the soil at the time of sowing is not fully available to the plants as the crop approaches maturity. Supplemental foliar application is one of the many techniques in seed agronomy that caters to seed nutrition at the most vulnerable stage i.e. seed filling (Shibles et al., 1975).

Keeping in view the above fact, the present study entitled Studies on foliar application of nutrients on the performance of urdbean (Vigna mungo (L.) Hepper) was carried out at Norman E. Borlaug Crop Research Centre of G.B. Pant University of Agriculture and Technology, Pantnagar, Udham Singh Nagar (UK) during kharif season 2014-15.

\section{Materials and Methods}

An experiment was conducted during kharif 2014 at N. E. Borlaug Crop Research Centre of Govind Ballabh Pant University of Agriculture and Technology, Pantnagar (Uttarakhand). The daily temperature during the study period varied between a minimum of $15.5^{\circ} \mathrm{C}$ to a maximum of $34.3^{\circ} \mathrm{C}$. The mean annual rainfall is $1400 \mathrm{~mm}$. The soil of the experimental field was a silty clay loam in texture being medium in available nitrogen (264.8 kg/ha) and sulphur $(26.8 \mathrm{~kg} / \mathrm{ha})$ and low in available boron $(0.45 \mathrm{ppm})$ and zinc (0.40ppm) but high organic carbon $(0.90 \%)$ contents with neutral in reaction $(\mathrm{pH} 7.45)$. The experiment was laid out in a randomized block design with three replications. There were twelve treatments as follows; T1 Control (Water Spray), T2 (2 \% urea), T3 (2\% SSP), T4 (0.1\% Zinc EDTA), T5 (0.2\% B (Borax), T6 (2\% Urea + $2 \%$ SSP), T7 (2\% Urea + 0.1 $\%$ Zinc EDTA), T8 (2\% Urea + $0.2 \% \mathrm{~B}$ (Borax), T9 (2\% Urea $+2 \%$ SSP $+0.1 \%$ Zinc EDTA), T10 (2\% Urea + $2 \%$ SSP + 0.2 $\%$ B (Borax), T11 (2\% Urea $+0.1 \%$ Zinc EDTA + $0.2 \%$ B (Borax) and T12 (2\% Urea $+2 \% \mathrm{SSP}+0.1 \%$ Zinc EDTA + $0.2 \% \mathrm{~B}$ (Borax). Urdbean, variety Pant U-31 was sown@15 kg/ha. The seeds were placed in furrows at a depth of 3-4 cm from soil surface on July 30, 2014. Row to row distance was maintained at $30 \mathrm{~cm}$. The gross plot size was $5.0 \mathrm{~m} \times 3.0 \mathrm{~m}$. A uniform dose of $18 \mathrm{~kg} \mathrm{~N}, 48$ $\mathrm{kg} \mathrm{P} 2 \mathrm{O} 5$ and $24 \mathrm{~kg} \mathrm{~K} 2 \mathrm{O} / \mathrm{ha}$ was applied as basal through NPK mixture (12:32:16) at the time of sowing. Pre emergence herbicide was done with the help of a hand operated knapsack sprayer fitted with flat-fan nozzle at the time of sowing. One irrigation was given to the crop due to sort of rainfall. During the crop period, a total rainfall of $398.4 \mathrm{~mm}$ was received. Harvesting was done in the month of October when most of the $(80 \%)$ pods turned brown in colour from the net plot (4.0 $\mathrm{m} \times 1.8 \mathrm{~m})$. The growth and yield attributes 
were recorded from five selected plants in each plot. Protein content in grains at maturity was worked out by multiplying nitrogen percentage of grains at maturity with 6.25. After getting protein content, the protein yield was calculated by multiplying with corresponding oven dried grain yield ( $\mathrm{kg} / \mathrm{ha})$.

\section{Results and Discussion}

\section{Yield}

Foliar combinations of nutrient management practices, in general, influenced the biological yield of urdbean significantly. Highest Urdbean biological yield (5893 kg ha-1) was recorded in treatment T12 (2\% Urea $+2 \%$ $\mathrm{SSP}+0.1 \%$ Zinc EDTA + $0.2 \%$ Borax whereas lowest yield (3172 kg ha-1) was noticed in control (water spray). Straw yield also recorded highest in case of T12 (2\% Urea $+2 \% \mathrm{SSP}+0.1 \%$ Zinc EDTA $+0.2 \%$ Borax) and the lowest in case of control (water spray). Rahman et al., (2012) also drew similar lines in their studies conducted in Pakistan.

\section{Economics}

The data on economic studies revealed that the maximum net returns were made under T12 (2\% Urea $+2 \% \mathrm{SSP}+0.1 \%$ Zinc EDTA + $0.2 \%$ B (Borax), whereas, the minimum remained under the water spray. After T12 (2\% Urea + $2 \%$ SSP $+0.1 \%$ Zinc EDTA + $0.2 \%$ B (Borax), the maximum net return were obtained under T11 (2\% Urea + $0.1 \%$ Zinc EDTA + $0.2 \%$ Borax) treatment.

Table.1 Biological yield, Cost of cultivation, gross return, net profit and B: C ratio as influenced by different foliar nutrient management practices

\begin{tabular}{|c|c|c|c|c|c|c|}
\hline & Treatments & $\begin{array}{l}\text { Biological } \\
\text { yields } \\
\text { (Kg/ha) }\end{array}$ & $\begin{array}{l}\text { Cost } \\
\text { of } \\
\text { cultivation }\end{array}$ & $\begin{array}{l}\text { Gross } \\
\text { return }\end{array}$ & $\begin{array}{l}\text { Net } \\
\text { return }\end{array}$ & $\begin{array}{l}\text { B:C } \\
\text { ratio }\end{array}$ \\
\hline $\mathrm{T}_{1}$ & Control (Water Spray) & 3172 & 20990 & 63310 & 42322 & 2.0 \\
\hline $\mathrm{T}_{2}$ & $2 \%$ urea & 4205 & 21123 & 71670 & 50509 & 2.3 \\
\hline $\mathrm{T}_{3}$ & $2 \% \mathrm{SSP}$ & 4040 & 21230 & 75840 & 54610 & 2.5 \\
\hline $\mathrm{T}_{4}$ & $0.1 \%$ Zinc EDTA & 5024 & 22390 & 84800 & 62410 & 2.7 \\
\hline $\mathrm{T}_{5}$ & $0.2 \%$ B (Borax) & 4360 & 21050 & 75852 & 54805 & 2.6 \\
\hline $\mathrm{T}_{6}$ & $2 \%$ Urea $+2 \% \mathrm{SSP}$ & 4960 & 21363 & 82445 & 51082 & 2.3 \\
\hline $\mathrm{T}_{7}$ & $2 \%$ Urea $+0.1 \%$ Zinc EDTA & 5864 & 22523 & 91390 & 68870 & 3.0 \\
\hline $\mathrm{T}_{8}$ & $2 \%$ Urea $+0.2 \%$ B (Borax) & 5590 & 21050 & 81815 & 60770 & 2.8 \\
\hline $\mathrm{T}_{9}$ & $2 \%$ Urea $+2 \% \mathrm{SSP}+0.1 \%$ Zinc EDTA & 5870 & 22763 & 93770 & 71005 & 3.1 \\
\hline $\mathrm{T}_{10}$ & $2 \%$ Urea $+2 \% \mathrm{SSP}+0.2 \% \mathrm{~B}($ Borax $)$ & 4830 & 21423 & 86602 & 69163 & 3.2 \\
\hline $\mathrm{T}_{11}$ & $\begin{array}{l}2 \% \text { Urea }+0.1 \% \text { Zinc EDTA }+0.2 \% \text { B } \\
\text { (Borax) }\end{array}$ & 5871 & 22583 & 95660 & 73080 & 3.2 \\
\hline \multirow[t]{3}{*}{$\mathrm{T}_{12}$} & $\begin{array}{l}2 \% \text { Urea }+2 \% \mathrm{SSP}+0.1 \% \text { Zinc EDTA } \\
+0.2 \% \mathrm{~B}(\text { Borax })\end{array}$ & 5893 & 22823 & 98054 & 75231 & 3.3 \\
\hline & SEm \pm & 391 & - & - & - & - \\
\hline & $\mathrm{CD}(\mathrm{P}=0.05)$ & 1150 & - & - & - & - \\
\hline
\end{tabular}


Fig.1 B: C ratio as influenced by different foliar nutrient management practices

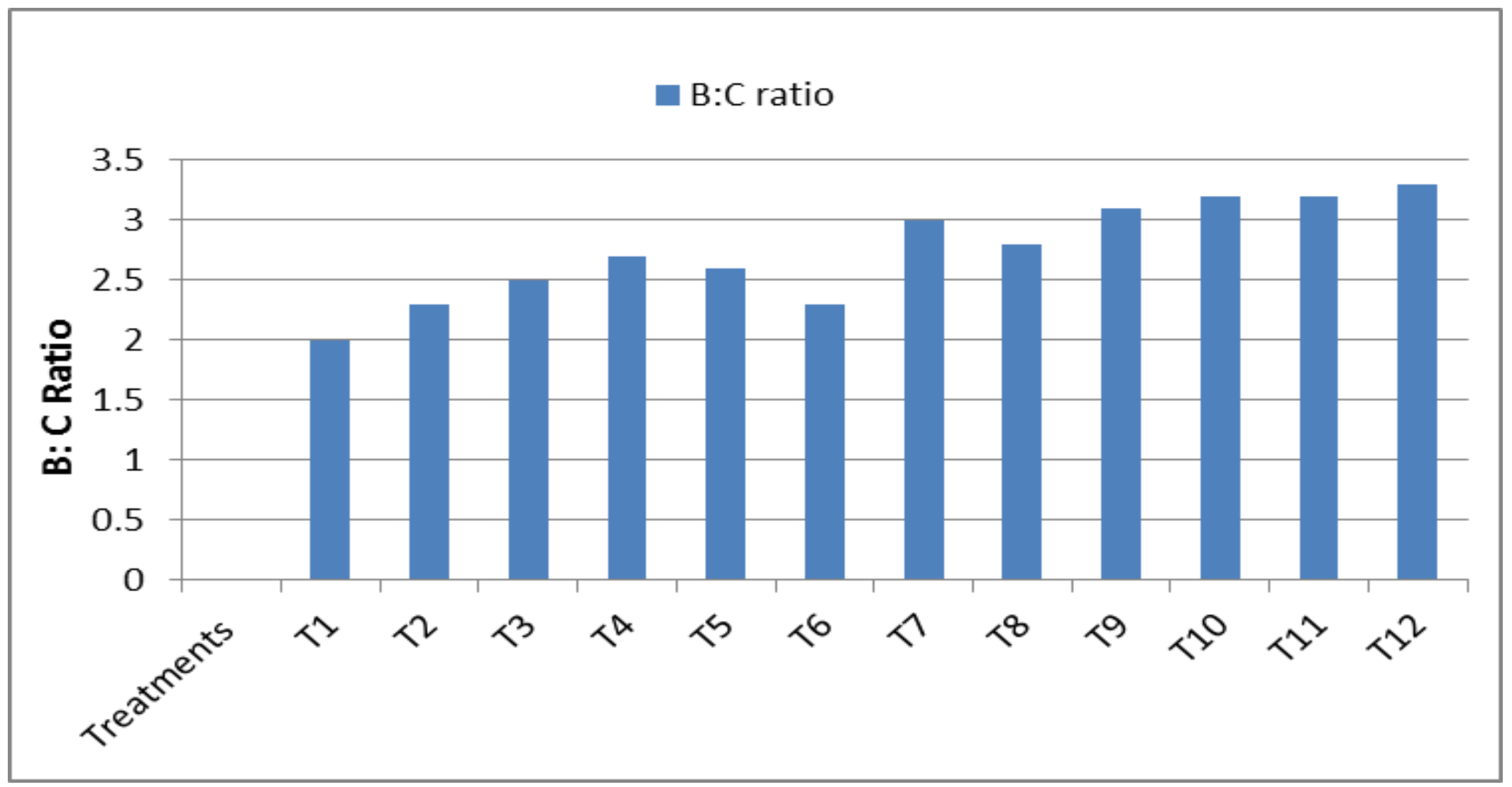


The maximum B: $\mathrm{C}$ ratio was also obtained under T12 (2\% Urea $+2 \% \mathrm{SSP}+0.1 \%$ Zinc EDTA + $0.2 \%$ Borax $)$ followed by T11 (2\% Urea $+0.1 \%$ Zinc EDTA $+0.2 \%$ Borax), $\mathrm{T} 10$ (2\% Urea $+2 \% \mathrm{SSP}+0.2 \%$ Borax $)$ and T9 (2\% Urea + $2 \%$ SSP + $0.1 \%$ Zinc EDTA) whereas, the lowest $\mathrm{B}$ : $\mathrm{C}$ ratio was obtained in case water spray. The higher gross returns, net returns and $\mathrm{B}$ : $\mathrm{C}$ ratio obtained with these treatment were ultimately due to higher productivity in terms of yield in these treatments. Such results were supported by Yakadri and Thatikunta (2002), Chandrasekhar and Bangarusamy (2003), and Dixit and Elamathi (2007) confirm the above findings.

In conclusion, on the basis of the experimental findings, it can be concluded that the treatment T12 (2\% Urea + $2 \%$ SSP + $0.1 \%$ Zinc EDTA + $0.2 \%$ B (Borax)) may be taken as an alternative over the soil application to increase nutrient use efficiency and to get higher grain yield of urdbean during kharif season. However, in view of economics of production, T11 (2\% Urea +0.1 $\%$ Zinc EDTA + $0.2 \%$ B (Borax) can also be a suitable alternative, foliar application of micronutrient increased biological yield, net return and $\mathrm{BC}$ ratio of urdbean.

\section{References}

Anonymous. 2014. Project Coordinator's Report. All India Co-ordinated Research Project on MULLaRP. Annual Group
Meet on mungbean and urdbean, May 17-18, CCS Haryana Agricultural University, Hisar. p 16.

Asaduzzaman, M., Sultana, S., Roy, T.S. and Masum, S.M. 2010. Weeding and plant spacing effects on the growth and yield of blackgram. Bangladesh Res. Publication J., 4(1): 62-68.

Chandrasekhar, C.N. and Bangarusamy, U. 2003. Maximizing the yield of mung bean by foliar application of growth regulating chemicals and nutrients. Madras Agric. J., 90(1-3): 142-145.

Dixit, P.M. and Elamathi, S. 2007. Effect of foliar application of DAP, micronutrients and NAA on growth and yield of green gram (Vigna radiata L.). Legume. Res., 30(4): 305-307.

Rahman, M., Imran, M. and Ashraf, U.M. 2012. Effect of inoculant on yield and yield contributing characters of summer mungbean cultivars. J. Environ. Sci. Natural Res., 5(1): 211-215.

Selim, M.M. 1992. Egyptian J. Agron., 17(1-2): 141-154.

Shashikumar, R., Basavarajappa, S.R., Salakinkop, Manjunatha Hebbar, M.P., Basavarajappa and Patil, H.Y. 2013. Legume Res., 36(5): 422-428.

Shibles, A.G. and Anderson, C. 1975. Soybean. In Crop Physiology (Evans, L.T. Ed) Cambridge University Press, Cambridge, London, p. 151- 189.

Yakadri, M. and Thatikunta, R. 2002. Effect of soil application of potassium and DAP spray in blackgram (Vigna munga L.). Madras Agric. J., 89(1-3): 147-149.

\section{How to cite this article:}

Dharmendra Meena, Chandra Bhushan, Anil Shukla, Sumit Chaudhary and Shiv Singh Meena. 2017. Effect of foliar application of nutrients on biological yield and economics urdbean (Vigna mungo (L.) Hepper). Int.J.Curr.Microbiol.App.Sci. 6(5): 2658-2662.

doi: https://doi.org/10.20546/ijcmas.2017.605.297 